\title{
Nephrogenic diabetes insipidus, cystinosis, and vitamin D
}

\author{
Z KATZIR, ${ }^{*} \S$ Y SHVIL,$\dagger \mathrm{H}$ LANDAU, $\dagger \mathrm{G}$ KIDRONY $\ddagger$ AND M M POPOVTZER \\ Departments of Pediatrics, *Hadassah Mount Scopus and †Ein Kerem University Hospitals, $\ddagger$ Bone and \\ Minerals Research Laboratory, Hadassah University Hospital-Mount Scopus, and the \$Nephrology Services, \\ Hadassah University Hospital-Ein Kerem, Jerusalem, Israel
}

SUMmary We describe a patient with early diagnosed cystinosis who presented with nephrogenic diabetes insipidus in addition to proximal tubular dysfunction. Another feature in this patient was abnormally low serum concentration of 24,25 dihydroxy vitamin $\mathrm{D}_{3}\left(24,25(\mathrm{OH})_{2} \mathrm{D}_{3}\right)$ with normal 25 hydroxy vitamin $\mathrm{D}_{3}\left(25(\mathrm{OH}) \mathrm{D}_{3}\right)$ and relatively low 1,25 dihydroxy vitamin $\mathrm{D}_{3}\left(1,25(\mathrm{OH})_{2} \mathrm{D}_{3}\right)$.

Cystinosis is a disorder of cystine metabolism with autosomal recessive inheritance. In this disease cystine is stored intracellularly in the lysosomes. There are three known clinical forms of cystinosis: nephropathic-infantile, intermediate-juvenile, and the adult onset type, which is the only form where the kidneys are unaffected. ${ }^{1}$

The nephropathic form has been described with a variety of clinical manifestations. Almost all patients present with polydipsia, polyuria, anorexia, failure to thrive, growth retardation, typical brown yellowish skin and hair, rickets, hepatosplenomegaly, and corneal and retinal involvement. The laboratory findings reflect the biochemical abnormalities of Fanconi syndrome, hypothyroidism, and somatomedin $\mathrm{C}$ deficiency. ${ }^{2}{ }^{3}$

In this report we describe unusual tubular dysfunctions and an interesting abnormality in vitamin $\mathrm{D}$ metabolism in an early diagnosed case of cystinosis.

\section{Case report}

A girl aged 25 months was admitted because of polydipsia, polyuria, and failure to thrive; the symptoms had begun at 8 months of age. Pregnancy and delivery were uneventful. Birth weight was $4500 \mathrm{~g}$. Family history showed that three of the child's siblings had died: two boys and one girl. One boy had suffered from polydipsia and polyuria and died at the age of $2 \frac{1}{2}$ years. Another boy had died after intractable vomiting and diarrhoea at 6 months of age, and one girl died from an unknown cause at the age of 4 months. The other members of the family and two parents were healthy. Developmental milestones were normal in our patient.

On admission the child's weight was $7900 \mathrm{~g}$ and the height was $71 \mathrm{~cm}$, both below the third percentile. Heart rate was 116 beats/minute and blood pressure was $100 / 70 \mathrm{~mm} \mathrm{Hg}$. Physical examination was otherwise normal.

Laboratory investigations showed hyponatraemia with serum sodium concentration of $129 \mathrm{mmol} / \mathrm{l}$ (normal range 135-145 mmol/l) and hypokalaemia with serum potassium concentration of $2.9 \mathrm{mmol} / 1$ (normal range $3 \cdot 5-5 \cdot 0 \mathrm{mmol} / \mathrm{l}$ ), serum urea concentration of $9.3 \mathrm{mmol} / \mathrm{l}$ (normal range $1.5-7 \mathrm{mmol} / \mathrm{l}$ ), and creatinine concentration of $119 \mu \mathrm{mol} / \mathrm{l}$ (normal $80 \mu \mathrm{mol} / \mathrm{l}$ ). Serum alkaline phosphatase activity was $822 \mathrm{IU} / \mathrm{l}$ (a normal result for this age is less than $300 \mathrm{IU} / \mathrm{l})$, serum phosphorus concentration ranged between 0.96 and $1.43 \mathrm{mmol} / \mathrm{l}$ (normal range for this age $1.4-2.0 \mathrm{mmol} / \mathrm{l})$, and calcium concentration was $2 \cdot 4 \mathrm{mmol} / \mathrm{l}$ (normal range $2 \cdot 0-2 \cdot 6 \mathrm{mmol} / \mathrm{l}$ ). Glucose, total protein, albumin, and liver enzymes were within normal limits. Capillary $\mathrm{pH}$ was 7.4 (normal range 7.38-7.42), serum bicarbonate was 20 $\mathrm{mmol} / \mathrm{l}$ (normal range $20-23 \mathrm{mmol} / \mathrm{l}$ ). Urinalysis showed traces of albumin and glucose on several occasions. Tubular reabsorption of phosphorus was $67 \%$ (normal $85 \%$ ). A random urine osmolarity measurement was $114 \mathrm{mmol} / \mathrm{kg} \mathrm{H}_{2} \mathrm{O}$. Urinary output was $2000 \mathrm{ml} / 24$ hours.

An $x$ ray film showed that her bone age was in the lower range for her chronological age. There was no radiological evidence of rickets.

A seven hour water deprivation test terminated by an intranasal deamino-8-D-arginine vasopressin (DDAVP) test was performed. ${ }^{4}$ Urine osmolarity increased from $121 \mathrm{mmol} / \mathrm{kg} \mathrm{H}_{2} \mathrm{O}$ to $148 \mathrm{mmol} / \mathrm{kg}$ $\mathrm{H}_{2} \mathrm{O}$ only. Therefore the diagnosis of nephrogenic diabetes insipidus was made. Treatment by hydrochlorothiazide and indomethacin caused a reduction in urinary output to $1000-1400 \mathrm{ml} / 24$ hours, cessation of polydipsia, improvement in appetite, and a weight gain of $500 \mathrm{~g}$ within one week.

At the age of 32 months she had grown only $3 \mathrm{~cm}$ during the previous seven months. Hepatosplenomegaly and clinical signs of rickets were first detected. Her growth retardation became more pronounced than the lag in weight gain and was appreciably below the third percentile $(74 \mathrm{~cm})$. A brown yellowish colour of her skin and hair was noticed. 
Laboratory investigations showed metabolic acidosis $(\mathrm{pH} 7 \cdot 28$, serum bicarbonate concentration 15 $\mathrm{mmol} / \mathrm{l})$, persistence of high serum urea and creatinine concentrations, low serum phosphorus, high alkaline phosphatase activity and normal calcium concentration. Serum sodium and potassium concentrations were normal.

Vitamin $\mathrm{D}$ metabolites concentrations were: $1,25(\mathrm{OH})_{2} \mathrm{D}_{3} 59.76 \mathrm{pmol} / \mathrm{l}, 25(\mathrm{OH}) \mathrm{D}_{3} 67.6 \mathrm{nmol} / \mathrm{l}$, both in the normal range ( $>46.8 \mathrm{pmol} / \mathrm{l},>39 \mathrm{nmol} / \mathrm{l}$, respectively). Concentrations of $24,25(\mathrm{OH})_{2} \mathrm{D}_{3} 1 \cdot 42$ $\mathrm{nmol} / \mathrm{l}, 1 \cdot 15 \mathrm{nmol} / \mathrm{l}$, and $1.17 \mathrm{nmol} / \mathrm{l}$ were found in three separate samples (normal $2 \cdot 5-10 \mathrm{nmol} / \mathrm{l}$ by high performance liquid chromatography depending on $25(\mathrm{OH})$ vitamin $\mathrm{D}$ concentration). ${ }^{5}$ Concentrations of thyroid hormones were triiodothyronine $\left(\mathrm{T}_{3}\right) 3.06 \mathrm{nmol} / \mathrm{l}$ (normal range $1.25-3.14 \mathrm{nmol} / \mathrm{l}$ ) and thyroxine $\left(\mathrm{T}_{4}\right) \quad 130.8 \mathrm{nmol} / \mathrm{l}$ (normal $59-158$ $\mathrm{nmol} / \mathrm{l})$.

Results of urine examinations were: $\mathrm{pH} \mathrm{6.5-7}$ and the glucose and protein traces intermittently persisted. Tubular reabsorption of phosphorus was $63 \%$, nephrogenous cyclic adenosine 5 monophosphate (cAMP) was $1438 \mathrm{pmol} / \mathrm{ml}$ glomerular filtration rate (GFR) (normal 1000-2000 pmol/ml GFR). Chromatography of the urine did not show aminociduria.

Bone $x$ ray films showed severe rachitic changes. Bone age corresponded to $1 \frac{1}{2}$ years. Intravenous pyelography and kidney ultrasonography gave normal results.

Bone marrow aspiration showed cystine crystals. There was a high free cystine content of peripheral leukocytes: $4 \cdot 14 \mu \mathrm{mol} 1 / 2$ cystine/g of protein $(50$ times results from normal controls). Both findings were consistent with cystinosis. Slit lamp microscopy did not visualise corneal cystine crystals. Treatment with $1 \mathrm{mmol} / \mathrm{kg} / \mathrm{day}$ sodium bicarbonate corrected the metabolic acidosis and her appetite improved. Indomethacin was stopped because of high serum creatinine and urea concentrations but no improvement was noticed. During a follow up of one year, tubular disturbances continued. Tubular reabsorption of phosphorus was $64 \%$ and glycosuria appeared more often. Urine osmolarity was 162 $\mathrm{mmol} / \mathrm{kg} \mathrm{H}_{2} \mathrm{O}$ after 10 hours of water deprivation. Treatment included bicarbonate, hydrochlorothiazide, and cysteamine.

\section{Discussion}

Nephrogenic diabetes insipidus as the initial presentation of cystinosis has been described in only a few cases. ${ }^{2}$ It is possible that some patients with cystinosis with polyuria and polydipsia who are not routinely subjected to an antidiuretic hormone
$(\mathrm{ADH})$ test escape the diagnosis of nephrogenic diabetes insipidus. This specific test has not been performed in almost all the previously reported cases. We can assume, therefore, that the tubular defect in cystinosis may also affect the distal nephron. It is noteworthy that the proximal tubular abnormalities in this patient did not include aminoaciduria but the phosphaturia and occasional glycosuria were prominent findings. The former led to the clinical bone disease. In previous reports describing early diagnosed cases of cystinosis there were some patients showing an incomplete form of tubular defects referred to as 'partial Fanconi syndrome. ${ }^{2}$

The possibility of nephropathic cystinosis in this girl was raised because of the presence of 'nephrogenic diabetes insipidus', which as an isolated defect is inherited as a sex linked disease rarely found in such severity in female patients.

Analysis of serum vitamin $\mathrm{D}$ metabolites concentrations showed that the $24,25(\mathrm{OH})_{2} \mathrm{D}_{3}$ concentrations in our patient were much lower than those described in patients with vitamin D resistant rickets from other etiologies. Their fraction of total serum $25(\mathrm{OH}) \mathrm{D}_{3}$ was $2 \%$ in our patient, in comparison with $10 \%$ in normal children (figure). ${ }^{5}$ Serum $1,25(\mathrm{OH})_{2} \mathrm{D}_{3}$ and $25(\mathrm{OH}) \mathrm{D}_{3}$ concentrations were normal, but in view of low serum phosphate the concentration of $1,25(\mathrm{OH})_{2} \mathrm{D}_{3}$ can be considered as relatively low.

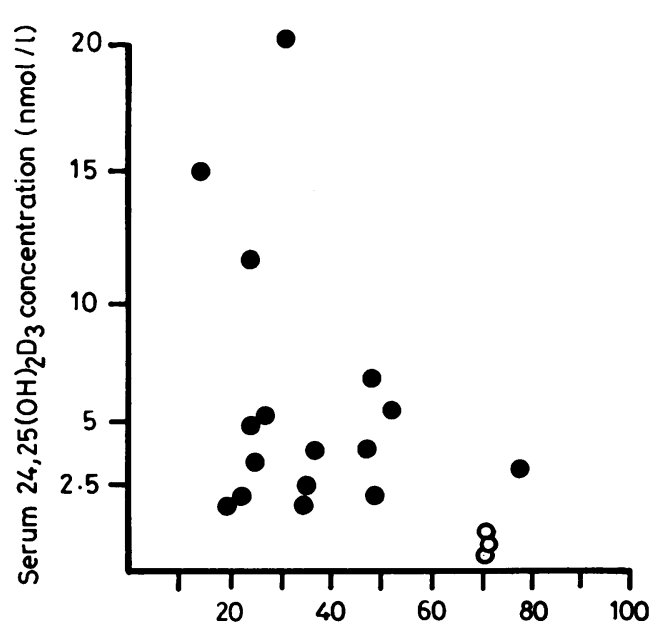

Serum $25(\mathrm{OH}) \mathrm{D}_{3}$ concentration ( $\mathrm{nmol} / \mathrm{l}$ )

Figure Relation between serum 24,25 dihydroxy vitamin $D_{3}\left(24,25(\mathrm{OH})_{2} D_{3}\right)$ and serum 25 hydroxy vitamin $D_{3}$ $\left(25(\mathrm{OH}) \mathrm{D}_{3}\right)$ concentrations in 16 normal children $\left(\mathrm{O}^{5}\right.$ and in our patient $(\mathrm{O})$. 
It is possible that 24-hydroxylase activity in the kidney is much more sensitive to the specific metabolic changes of cystinosis than that of $\alpha-1$ hydroxylase.

Although the phosphate leak, per se, could account for the pathogenesis of rickets, one cannot rule out that the low concentration of $24,25(\mathrm{OH})_{2} \mathrm{D}_{3}$ could also contribute to the bone disease in this patient. $^{6}$

\footnotetext{
References

'Schneider JA, Schulman JD. Cystinosis and the Fanconi syndrome. In: Stanbury JB, Wyngaarden JB. Fredrickson DS, eds. The metabolic basis of inherited disease. 5 th ed. New York: McGraw-Hill, 1982:1844.
}

2 Lemire J, Kaplan BS. The various renal manifestations of the nephropathic form of cystinosis. Am J Nephrol 1984;4:81-5.

${ }^{3}$ Bercu BB, Corden BJ, Schulman JD, et al. Circulating somatomedin-C levels in nephropathic cystinosis. Isr J Med Sci 1984;20:236-9.

4 Hendricks SA, Lippe B. Kaplan SA, et al. Differential diagnosis of diabetes insipidus: use of DDAVP to terminate the seven hour water deprivation test. J Pediatr 1981;98:244-6.

${ }^{5}$ Nguyen TM, Giullozo H, Garabedian M, et al. Serum concentrations of 24,25 dihydroxyvitamin $\mathrm{D}$ in normal children and in children with rickets. Pediatr Res 1979:13:973-6.

${ }^{6}$ Malluche HH. Henry H. Meyer-Sabellek W, et al. Effect and interactions of $24 \mathrm{R}, 25(\mathrm{OH}) \mathrm{D}$ and $1.25(\mathrm{OH}) \mathrm{D}$ on bone. $A m J$ Physiol 1980;238:E494-8.

Correspondence to Dr Z Katzir, Nephrology Services, Hadassah University Hospital, P.O. Box 12000, Jerusalem, il-91120 Israel.

Accepted 27 October 1987
SUMmary We report an infant with meningococcal septicaemia and meningitis who had panophthalmitis at presentation that was unresponsive to standard systemic antibiotic treatment but which responded to topical steroid and mydriatic treatment. The pathogenesis may have been immune mediated.

\section{Case report}

The patient, a 7 month old boy in whom there was no important family or perinatal medical history, had been unwell for three days before admission with cough, poor feeding, and diarrhoea. (On questioning later his mother recalled noting that his eyes were 'blood shot' two days before admission.) On the day of admission he deteriorated and developed a widespread rash. On admission he was ill but not shocked or hypotensive. Axillary temperature was $39^{\circ} \mathrm{C}$ and he had a widespread purpuric rash but no conjunctival petechiae, although both bulbar conjunctivae were injected. He was very irritable, noticeably photophobic, and had meningism. A clinical diagnosis of meningococcal meningitis was made and the following initial investigations performed: cerebrospinal fluid was turbid with $4.56 \times 10^{9} / \mathrm{l}$ leucocytes, glucose $0.1 \mathrm{mmol} / \mathrm{l}$, total protein $2.6 \mathrm{~g} / \mathrm{l}$ with raised globulins; Gram staining showed Gram negative diplococci, and both cerebrospinal fluid and blood culture subsequently confirmed Neisseria meningitidis (later reported as Group C) sensitive to benzylpenicillin and chloramphenicol. Peripheral blood count showed: haemoglobin $110 \mathrm{~g} / \mathrm{l}$, white blood count $22 \cdot 8 \times 10^{9} / \mathrm{l}$ with $57 \%$ neutrophils and platelets $312 \times 10^{9} / 1$.

Treatment was started with intravenous benzylpenicillin $300 \mathrm{mg} / \mathrm{kg} / \mathrm{day}$ and his general condition gradually improved. Photophobia persisted as well as low grade fever, however, although his meningism resolved and there were no localising neurological signs. On the seventh day of treatment a repeat examination of the cerebrospinal fluid gave normal results, and a computed tomogram was normal with no evidence of abscess or subdural collection. Antibiotic treatment was stopped on the eighth day.

An ophthalmological opinion was obtained 12 days after admission as his eyes continued to be red, and he was photophobic with a low grade temperature. The appearances were suggestive of uveitis with limbal injection; and he had miosed nonreactive pupils, fibrinous exudates in the anterior chamber, and a dull red reflex. Topical treatment with prednisolone $0.5 \%$ drops and cyclopentolate $1 \%$ was started and within two days he had considerably improved, he was not feverish and had minimal photophobia.

An examination under general anaesthetic later confirmed the diagnosis of anterior uveitis; dilated iris vessels and posterior synechia were found in both eyes. The pupils continued to be poorly dilated and phenylephrine $2.5 \%$ drops were added to the 